\title{
Multinomial Logistic Regression Analysis of Livelihood Diversification Strategies of Rural Farm Households: A Case of Limmu District, East Wollega Zone of Oromiya Regional State, Ethiopia
}

\author{
Dawit Sekata Duressa \\ Department of Statistics, Wollega University, PO box 395, Nekemte, Ethiopia
}

\begin{abstract}
This study investigated the factors that influence the choice of livelihood strategies in rural areas of households in Limmu District, eastern Wollega zone of Oromiya regional state, Ethiopia. 292 households' were selected using multi stages random and purposive sampling technique. A Multinomial logit regression model was applied to identify the determinants of agricultural diversification strategies in the area. Out of the total sample household heads about $46 \%$ of the total household income was derived from on farm only, $30 \%$ from a combination of on farm and nonfarm, about $12.33 \%$ from a combination of on farm, non-farm and off-farm and $12 \%$ from a combination of on farm and off-farm activities. The multinomial logit regression analysis revealed that education level, access to credit, access to mass media, dependency ratio, access to irrigation, urban linkage, climate change, extension contact and distance to the nearest road were theoretically consistent and statistically significant effect to the likelihood choice of diversification strategies. Whereas, age of household head, sex, distance to the market, cooperative membership, crop risk and distance from market were insignificant predictor of diversification strategy at 5\% significance level. The findings of the study suggest that efforts should focus on the promotion of options, substitution between assets and activities to diversify household specific agriculture-linkage with non-farm and off farm diversification rather than focusing on the single agricultural productive farm by taking action to improve information, mobility and asset accumulation.
\end{abstract}

Keywords: Multinomial Logit, Limmu, Livelihood diversification, on farm, off-farm, non-farm

DOI: $10.7176 / \mathrm{JESD} / 12-13-03$

Publication date:July $31^{\text {st }} 2021$

\section{Introduction}

Globally, agriculture accounts for $67 \%$ of employment, $39.4 \%$ of national gross domestic product, and $43 \%$ of export goods (FAO, 2015). As the world's population continues to grow, the demand for food and livelihood security is therefore a pressing concern of development planners and researchers. This is especially true in SubSaharan African countries, where more than three-fourths of the population is essentially dependent on rain-fed agriculture and land degradation is the principal cause of the reduction in production and productivity (Rosegrant, M.W., et al). In rural areas of developing countries like Ethiopia, households combine diverse portfolios of activities in their pursuit of alleviating poverty and improving living standards (Ellis F., 2000; Alobo Loison S., 2015). In Africa, for instance, rural livelihood is assertively connected to agriculture and natural resource use. Davis et al. (2010), affirmed that roughly 90 percent of rural households are involved in farming activities, while in Asia and Latin America, 50 percent of the income is from farming activities (Davis et al., 2010). Though agriculture is the spine of livelihood in India, yet the majority of the uneducated agrarians have not been efficacious in tilling their land for maximum economic gain (Hedge, 2002). Mahendra (2011) also confirmed that the principal source of living for many of the Asia-Pacific countries is derived from agriculture; however, some other countries have an ample share of livelihood obtained from non-rural farming activities. Livelihood diversification is a process by which rural households construct a diverse portfolio of activities and social support capabilities in their struggle for survival and improvement in their standards of living (Ellis F., 2000) and the means of gaining a living (Chambers JK., 1995). It can be defined as the maintenance and continuous alteration of highly varied range of activities and occupations to minimize household income variability, reduce the adverse impacts of seasonality, and provide employment or additional income (Ellis F., 2000; Barrett CB, 2001; Alobo Loison S., 2015). Ahmed et al. (2015) reported that the livelihood of rural Bangladesh mainly consists of farm activities with few non-farm activities.

Agriculture serves as the primary means of rural households' livelihood in Ethiopia, which contributes 38.8 percent to GDP, share more than 80 percent of employment opportunities and 90 percent of the foreign exchange of the country (Admit W. et al, 2016). According to Lemi (2009), there in Ethiopia subsistence farming, limited arable land and low agricultural productivity compel individuals or households to diversify livelihoods. As country level, Asfaw (2018) carried out a study on "determinants of sustainable rural livelihood diversification of small holder farmers in Ethiopia". Nevertheless, Sisay (2013) and Sarah (2015) study on "Rural livelihood 
diversification" in some Africa countries and sub-Saharan Africa, respectively. However, due to the smaller farm size and low return from farming activities, majority of rural households are exposed to food insecurity and chronic poverty. Climate change is a global phenomenon with growth, poverty, food security, and stability implications. Because of significant dependence on the agricultural sector for production, employment, and export revenues, Ethiopia is seriously threatened by climate change, which contributes to frequent drought, flooding, and rising average temperatures (Kassie, G.W., 2017). In rural Ethiopia the prevalence of extreme land pressure has resulted in vast deforestation and cultivation of unsuitable slopes, causing sever environmental damages, which make the future prospects of agriculture look bleak without generating non-agricultural activities (Desalegn, 2009). Thus, a considerable proportion of rural farm households in Ethiopia involved in non/off-farm activities. For example, Beyene (2008) study in rural Ethiopia indicated that $57.3 \%$ of the farm households have one or more members participating in off-farm activities (self-employment 43\% and wage employment $25.3 \%$ ). Sara (2007) found that about $75 \%$ of rural households in Olankomi district, Oromia region were engaged in non/off farm activities and about $31 \%$ of their livelihood income is generated from non/off farm employment. Gebru et al. (2018) also found that 83.1 percent of rural households in Tigray region were engaged in non/off-farm livelihood strategies to pursue their livelihood income. Hence, it is crucial to recognize that rural people have their own strategies to secure their livelihoods which vary from household to household depending on numerous factors such as their socio-economic status, education and local knowledge, ethnicity, and stage in the household lifecycle. Even in some locality there can be a big distinction between the strategies of those with different socioeconomic background, for example, for those with more land and those who are with less land or landless (Wegayehu, 2004). In line with this view, this study intends to identify the existing livelihood strategies, and assess the contextual and location specific determinants of livelihood diversification strategies and the effect of climate change on crop production in Limmu District.

\section{Methodology}

\subsection{Description of the Study Area}

The study was conducted in Limmu district which is located at $460 \mathrm{~km}$ from the capital city Addis Ababa and at $132 \mathrm{~km}$ from Nekemte (zonal town east Wollega) in the Northwest Ethiopia. The district is bounded by Sasiga from the south, Gida Ayana district from the East, Ebantu district from the north and Haro Limmu District district from the west. The altitude of the district ranges from 1200-2350 meter above sea level which is considered to be "Woinadega" and receives annual rainfall of 1500-3000 mmHg which occurs mainly in may, June, July, August and September. In general, the weather condition is a hospitable environment for the moderately dense population that ranges from 50 to 260.22 people per $\mathrm{km}^{2}$. In 2019, Limmu district has a total population of 46,705 which is settled in 18 kebele administrations with one town municipality (having 2 kebeles) and 16 rural kebele's. In the district, most people (87\%) are engaged in agricultural activities as a major livelihood means (EWFED, 2019). From the 16 kebele administrations in the study district, three rural kebeles namely Degem Sellasie, Gaba Kamisa and Arkumbe were the study sites.

\subsection{Farming Activities in the District}

A mixture of crop production and livestock rearing activities farming system based upon rains with minimum irrigation practices was mainly known in the study area. Teff, Maize, Wheat, Barley, Finger millet, Sesame and Sorghum are the dominant and most important crops, serving as both the main food and cash crops in the district. According to Limmu district agricultural and rural development office (2019), about 31,781.06 ha of land were cultivated through rain-fed agriculture in the in 2018/2019 production year. The small scale irrigation activities are not expanded in the study area. In addition to these, livestock such as Cattle, Sheep, Goats, Donkeys, Horses, Honey bee production and Chickens are the most significant source of their cash earnings. Oxen are used to provide traction power for land preparation activities.

To determine the children to be included in the study, different methods were employed in order to get representative sample size. Therefore, Cochran (1963:75) formula to yield the required sample for proportions was used (Cochran, W. G. 1963). Thus,

$$
n_{0}=\frac{\left(z_{\alpha / 2}\right)^{2} p q}{E^{2}}
$$

Which is valid where $n_{0}$ - is the sample size, $z_{\alpha / 2}$ - is the abscissa of the normal curve that cuts off an area $\alpha$ at the tails ( $1-\alpha$ equals the desired confidence level, e.g., 95\%), $E_{-}$is the desired level of precision, $p$ - is the 
estimated proportion of an attribute that is present in the population, and $q$ is $1-p$. Accordingly, the sample size for the quantitative study was determined using a single population proportion formula above with the following assumption: the estimated proportion of an households that are engaged in both in a mixture of crop production and livestock rearing activities is estimated to be 54.6\% (CSA, 2016), margin of sampling error tolerated $5 \%(0.05)$, and critical value at 95\% confidence interval of certainty (1.96) resulting sample size demonstrated below.

$n_{0}=\frac{\left(z_{\alpha / 2}\right)^{2} p q}{E^{2}}=\frac{(1.96)^{2} 0.546 \times 0.454}{(0.05)^{2}} \approx 381$

For Proportions If the population is small then the sample size can be reduced slightly. Assuming a given sample size provides proportionately more information for a small population than for a large population, the sample size $\left(n_{0}\right)$ can be reduced slightly using finite population correction equation making the final sample size of the households as follows.

$$
n=\frac{n_{0}}{1+\frac{\left(n_{0}-1\right)}{N}}=\frac{381}{1+\frac{(381-1)}{1230}} \approx 292
$$

Assuming our evaluation of farmers' adoption of the livelihood diversification strategies only affected 1,230 farmers of the district, the sample size that would now be necessary is adjusted to 291 households. Then, three kebeles (Degem Sillasie, Gaba Kamisa, and Arkumbe) were selected using a stratified random sampling techniques proportionally allocating according to the number of total households in each kebele by the help of Limmu district agriculture and rural development office.

\subsection{Data Types, Data Sources, and Methods of Collection}

Obtained from sample household head interviews, both qualitative and quantitative data were used in this study. Qualitative data focused on the expressions and feelings of smallholder farmers, key informants, and focus group discussion participants. It were included the common animal and crop diseases, infrastructural facilities, and the purposes of different local institutions. The quantitative types of data were collected through both primary and secondary methods of data collection. Primary data collection methods uses structured sample household head interviews, focus group discussions, observations, and key informant interviews. Structured sample household head interviews were employed to generate household level data on household assets (like age, sex, dependency ratio, land size, extension contact, education level of household heads, households use of irrigation, membership to cooperatives and local institutions, household use of credit, saving habit, access to mass media, land tenure security etc.) households livelihood activities, strategies and incomes, and the constraints of livelihood diversification strategies. The interview schedule was pre-tested among 10 randomly selected non sampled households in the other kebele having similar/matched characteristics to the study kebeles and based on the results of the pre-test necessary corrections/modifications were made.

Key Informant Interviews (KIIs) such as Development agents, Kebele administrations, model farmers, elder informants, different caste group members like weavers, blacksmith participants, and tannery persons were also interviewed. The major points of discussion during key informant interviews were the accessibilities of infrastructural facilities such as roads, public transport services, school facilities, health services, and access to markets; common animal and crop diseases, the purposes of different livelihood assets like membership to cooperatives and local institutions, livelihood activities, and the constraints of non/off-farm livelihood diversification strategies. Focus Group Discussions (FCDs) were also held based on gender and land size. The discussion was aimed to elicit different opportunities and constrains of landless and small holder farm households' livelihood diversification strategies. Observations were particularly emphasized on the topography of the area, infrastructural facilities of the kebeles, the types of agricultural activities, non-farm activities and off-farm activities in this study area. Different records and reports of agriculture and rural development office on input, crop and animal diseases reviewed.

\subsection{Methods of Data Analysis}

Quantitative data were cleaned, edited, and entered onto STATA statistical software for analysis. Descriptive statistics such as frequency distribution, cross tabulations, percentages, means, standard deviations and graphs 
were as used to organize distribution of household's demographic and socio-economic, and environmental characteristics against the variables of interest. All the categorical predictor variables and metric covariate described previously were also modeled nonlinearly on the livelihood of diversification strategies using multinomial logistic regression model Wassie (2008). The response variable $Y_{i}=(0,1,2,3), i=1,2, \ldots, 291$, is indexed to be 0 if the $i^{\text {th }}$ household head diversify on farm only, 1 he/she diversify on plus none farm, 2 he/she diversify on plus off farm, and 3 if the $i^{\text {th }}$ household head diversify on + off + none farm activities. Note that the none farm only and off farm only livelihood diversification were ignore as the number of households that diversify these activities are negligible.

Following Greene (2003), suppose for the $i^{\text {th }}$ respondent faced with $J$ choices, the utility choice $\mathrm{j}$ can be specified as:

$$
\eta_{i j}=\log \left(\frac{\pi_{i j}}{\pi_{i J}}\right)=\alpha_{j}+x_{i}^{\prime} \beta_{j}
$$

Where $\alpha_{j}$ is a constant and $\beta_{j}$ is a vector of regression coefficients, for $j=1,2, \ldots, J-1$. Note that we have written the constant explicitly, so we will assume henceforth that the model matrix $X$ does not include a column of ones. Note that we need only $J-1$ equations to describe a variable with $J$ response categories and that it really makes no difference which category we pick as the reference cell, because we can always convert from one formulation to another. We will therefore entertain the model

$$
\eta_{i j}=\alpha_{j}+\beta_{j} \alpha_{i}+\gamma \alpha^{2}
$$

Where $\alpha_{j}$ is the average of the $i^{\text {th }}$ household and $j=1,2,3$ for on farm only, on plus none farm, and on plus off farm livelihood diversification respectively calling on plus off plus none farm activities as a baseline.

The multinomial logit model may also be written in terms of the original probabilities $\pi_{i j}$ rather than the logodds. Starting from the Equation (3) and adopting the convention that $\eta_{i J}=0$, we can write

$$
\pi_{i j}=\frac{\exp \left\{\eta_{i j}\right\}}{\sum_{i=1}^{k} \exp \left\{\eta_{i k}\right\}},
$$

for $j=1, \ldots, J$. To verify this result exponentiated Equation (3) to obtain $\pi_{i j}=\pi_{i J} \exp \left\{\eta_{i j}\right\}$, and note that the convention $\eta_{i J}=0$ makes this formula valid for all $j$. Next summing over $j$ and using the fact that $\sum_{j} \pi_{i j}=1$ to obtain $\pi_{i J}=\frac{1}{\sum_{j} \exp \left(\eta_{i j}\right)}$. Finally, we use this result on the formula for $\pi_{i j}$.

\section{Results and Discussion}

\subsection{Explanatory data Analysis Descriptive Results}

Before inferential analysis, let us go over the displayed outputs for each variable. As all respondents in this survey were participated in the study, there were no missing observations for the whole variables. Among the total sampled household heads 38.36\% were obtained from Degem Sillasie Kebele, 10.62\% from Gaba Kamisa and the remaining 51.03\% were from Arkumbe district. Table 3.1 (on appendix) depicts that $223(76.37 \%)$ of the sample of 292 respondents comprises male headed households and the remaining $69(23.63 \%)$ were females. As of the total sample household head about $46 \%$ of them were participating in agriculture only, $30 \%$ in agriculture, off farm and nonfarm; $12 \%$ in agriculture and nonfarm; $12 \%$ in agriculture, off farm and nonfarm livelihood strategies respectively. Thus, the largest number of sampled household heads were participating in agriculture only diversification strategy. It is a clear mode that near half of the household head (about 46.58\%) participated in the study was illiterate. The age of the sampled household under study ranged from 15 to 60 years old, majority of the lies between 17 to 50 years old $(85.62 \%)$. As stated by the respondents, the major challenge of the household heads in the study was lack of access to irrigation. With reference to the table, even if more than $79 \%$ of them were a 
membership of cooperative association, majority of the households have no likelihood of access to credit (51.20\%). Though roughly about $52 \%$ of the household heads had an access to mass media, about $56.51 \%$ of the household had frequently contacted with development agents greater part of them $(68.49 \%)$ reported that climate change had effected their production. These results could not be supported by the risks the households become manifested on their crops.

Now the investigator goes along with the variable diversification strategy of household head that might be depends on the Kebele, age, sex, and education attainment of the Household heads. The Stata software output is displayed in table 3.2 below.

Table 3.2: Diversification Strategies Cross-tabulated with Household Characteristics

\begin{tabular}{|c|c|c|c|c|c|c|}
\hline \multirow{2}{*}{$\begin{array}{l}\text { Household } \\
\text { Character }\end{array}$} & \multirow[b]{2}{*}{ Labels } & \multicolumn{5}{|c|}{ Diversification strategy } \\
\hline & & on farm only & $\begin{array}{l}\text { on+none } \\
\text { farm }\end{array}$ & $\begin{array}{l}\text { On+off } \\
\text { farm }\end{array}$ & $\begin{array}{l}\text { On+off }+ \text { no } \\
\text { farm }\end{array}$ & Total \\
\hline \multirow{4}{*}{ Kebele } & $\begin{array}{l}\text { Degem } \\
\text { Sillasie }\end{array}$ & $35(31.25 \%)$ & $37(33.04 \%)$ & $14(12.50 \%)$ & $26(23.21 \%)$ & $112(100 \%)$ \\
\hline & $\begin{array}{l}\text { Gaba } \\
\text { Kamisa }\end{array}$ & $16(51.61 \%)$ & $14(45.16 \%)$ & $1(3.23 \%)$ & $0(0.00 \%)$ & $31(100 \%)$ \\
\hline & Arkumbe & $83(55.70 \%)$ & $36(24.16 \%)$ & $20(13.42 \%)$ & $10(6.71 \%)$ & $149(100 \%)$ \\
\hline & Total & $134(45.89 \%)$ & $87(29.79 \%)$ & $35(11.99 \%)$ & $361(2.33 \%)$ & $292(100 \%)$ \\
\hline \multirow{4}{*}{ Age } & $<16$ & $2(100 \%)$ & $0(0.00 \%)$ & $0(0.00 \%)$ & $0(0.00 \%)$ & $2(100 \%)$ \\
\hline & $17-50$ & $114(45.60 \%)$ & $70(28.00 \%)$ & $35(14.00 \%)$ & $31(12.40 \%)$ & $250(100 \%)$ \\
\hline & $>50$ & $18(45.00 \%)$ & $17(42.50 \%)$ & $0(0.00 \%)$ & $5(12.50 \%)$ & $40(100 \%)$ \\
\hline & Total & $134(45.89 \%)$ & $87(29.79 \%)$ & $35(11.99 \%)$ & $36(12.33 \%)$ & $292(100 \%)$ \\
\hline \multirow{3}{*}{ Education } & Illiterate & $71(52.21 \%)$ & $38(27.94 \%)$ & $20(14.71 \%)$ & $7(5.15 \%)$ & $136(100 \%)$ \\
\hline & Literate & $63(40.38 \%)$ & $49(31.41 \%)$ & $15(9.62 \%)$ & $29(18.59 \%)$ & $156(100 \%)$ \\
\hline & Total & $134(45.89 \%)$ & $87(29.79 \%)$ & $35(11.99 \%)$ & $36(12.33 \%)$ & $292(100 \%)$ \\
\hline \multirow{3}{*}{ Sex } & female & $33(47.83 \%)$ & $17(24.64 \%)$ & $12(17.39 \%)$ & $7(10.14 \%)$ & $69(100 \%)$ \\
\hline & male & $101(45.29 \%)$ & $70(31.39 \%)$ & $23(10.31 \%)$ & $29(13.00 \%)$ & $223(100 \%)$ \\
\hline & Total & $134(45.89 \%)$ & $87(29.79 \%)$ & $35(11.99 \%)$ & $36(12.33 \%)$ & $292(100 \%)$ \\
\hline \multirow{3}{*}{ Climate Change } & no & $47(51.09 \%)$ & $29(31.52 \%)$ & $8(8.70 \%)$ & $8(8.70 \%)$ & $92(100 \%)$ \\
\hline & yes & $87(43.50 \%)$ & $58(29.00 \%)$ & $27(13.50 \%)$ & $28(14.00 \%)$ & $200(100 \%)$ \\
\hline & Total & $134(45.89 \%)$ & $87(29.79 \%)$ & $35(11.99 \%)$ & $36(12.33 \%)$ & $292(100 \%)$ \\
\hline
\end{tabular}

The frequencies and the percentages (in table 3.2) show that more than $31.25 \%$ of the household heads are residing in Degem Sillasie Kebele pursued on farm livelihood diversification strategy. However, majority of Degem Sillasie Kebele residents practices both on and none farm livelihood diversification strategy (33\%). In the same way households that reside in Gaba Kamisa Kebele commonly carry out an on farm strategy $51.61 \%$ and there were no household that put on farm, off farm and no farm into practice. This triple diversification activity were somewhat applied in Degem Sillasie Kebele, roughly about $23 \%$ of the practiced it. The climate change in the area of sampled household heads is believed to be an important feature that determines the agricultural diversification strategies. The empirical result shows that the risk due to climate change in the study area is considerably high. In the study area as a whole, a significant share (about $68.49 \%$ ) of the household heads had seen the risk due to climate change. The cross tabulation indicates that majority of the household that had seen the risk climate change still practices on farm agriculture only, about $46 \%$. Households whose ages exceed 50 years were relatively more likely to practice both on and none farm activities than the youngsters households $(42.5 \%)$. Even educated households were more often participated in on farm agriculture only than other diversification strategies, Analogous to the prospect made, the investigator report that only on farm agricultural activity were common practices at Limmu district regardless of any demographic, socio-economic and other decisive factors.

Table 3.3: Summary Statistics of Selected Quantitative Variables

\begin{tabular}{l|lllll|llll}
\hline & & & & & & \multicolumn{3}{l}{ Percentiles } \\
\cline { 7 - 10 } Item & Obs & Mean & Std. Dev. & Min & Max & $\mathbf{2 5 \%}$ & $\mathbf{5 0 \%}$ & $\mathbf{7 5 \%}$ & $\mathbf{9 0 \%}$ \\
\hline Land size & 292 & 1.686 & 1.903 & 0 & 25 & 0.5 & 2 & 2 & 3 \\
Access to market & 292 & 6.686 & 2.120 & 1 & 14 & 5 & 7 & 8 & 10 \\
Livestock & 292 & 18.324 & 23.345 & 0 & 439 & 9.055 & 15.4 & 292.98 & 395.9 \\
Dependency Ratio & 292 & 0.449 & 0.223 & 0 & 1 & 0.33 & 0.5 & 0.6 & 0.71 \\
Yearly Income & 292 & 11006.88 & 13406.18 & 150 & 103470 & 3825 & 7055 & 12850 & 22250 \\
Access to road & 292 & 1.23336 & 1.932 & 0.001 & 11 & 0.1 & 0.45 & 1 & 4 \\
\hline
\end{tabular}

The mean yearly income of the household heads in the district is 11,006.88 ETB with a standard deviation of 13406.18 ETB, which is mainly gained from agricultural activities. Large standard deviation in this income shows high variability between the incomes participants of the study. However, since the mean is easily affected by 
extreme values, the corresponding minimum and maximum value is 150 and 103,470 respectively, it would be hard to report it. Therefore, most of the researchers use the median to compute the central value. The median yearly income of the households in the study area was computed to be 7055 ETB. About 75 percent earns a monthly income less than 12,850 ETB. The average land size used by the household head is 1.686147 hectare with average deviation of 1.903117 hectare. There were household heads that had no farm land at all and there were families that had more than 25 hectare farm land. About half 50\% of the households had 2 hectares of land size for agricultural activities. Utmost, a household travels about $14 \mathrm{~km}$ distance from adjoining market but, only 10 percent of them tour 10 kilometer or more to arrive at a nearest market. At average, each household has approximately about $7 \mathrm{~km}$ away from the nearest input market. Thus, the distribution of the data shows that distance from the market is to some extent challenging. The average livestock holding status of the household were roughly two tropical livestock unit. The maximum livestock holding status of the household were reported to be 439 and the minimum is found to be zero. Households that had 9 or less livestock were not more than 25 percent. Livestock are also considered as indicators of wealth and prestige in rural areas. The wealth status is determined by sources of income and major occupations, which determine the livelihood of the household. Livestock production is the most important source of income. Hence, the number of cattle, camels, goats or sheep is a good indicator of the wealth status in the community. The overall mean dependency ratio of sample households was 0.4485616 with standard deviation of 0.2228328 which determines the livelihood diversification strategy of the household, participation of individuals in the labor market, the expenditure patterns and investment in the social sector. This is because economically productive age has to support itself as well as additional persons for their livelihood.

\subsection{Multinomial logistic regression}

First, a linear model was run on the response as a function of the predictors to ensure that there were no multicollinearity issues; only predictors with VIF $<2$ were included in this model. Table 3.4 provides the list of categorical socio-economic characteristics as well as the list of livelihood diversification strategies of the household heads in the survey was presented. After the most parsimonious model was selected, the full model contains the following variables order: education of house hold head, land size, Number of livestock, Access to irrigation, Access to credit, dependency ratio, Extension contact, Urban linkage, Access to mass media, Total income, Distance to the nearest road, and Climate change. Subsequently, the researcher should closely examine the fitted model with 12 predictor variables. The Log likelihood in the full model (Log likelihood $=-30.5711)$ is the smallest one which indicated the best model and the chi-square test of goodness of fit (LR chi2 $(42)=99.24$ with $\mathrm{p}$-value $=0.0000)$ tests the hypothesis that the multinomial logit regression model is considerably fine. This test is highly significant, indicating that one or more of the predictors are important in the model. Note that $R^{2}=$ 0.845 for the full model.

Table 3.4: Estimated Coefficients of each Predictors Variables

\begin{tabular}{|c|c|c|c|}
\hline $\begin{array}{lcc}\text { Log likelihood }= & -30.5711 \\
\text { LR chi2(42) } & =99.24 \\
\text { Pseudo R2 } & = & 0.8239 \\
\end{array}$ & $\begin{array}{l}\text { Number of obs }= \\
\text { Prob }>\text { chi } 2=\end{array}$ & $\begin{array}{r}291 \\
0.0000\end{array}$ & \\
\hline \multicolumn{4}{|c|}{ Livelihood Agricultural Diversification Strategies } \\
\hline Divers. Strategy & on+none farm & on+off farm & on+off+nonfarm \\
\hline Education (liltr.) & $0.197(0.31)^{* *}$ & $0.030(0.452) * * *$ & $0.145(0.507) *$ \\
\hline Land Size & $0.049(0.094)$ & $0.775(0.307) * *$ & $0.091(0.084)$ \\
\hline Num. Livestock & $-0.038(0.048) * * *$ & $-0.390(0.174) *$ & $-0.126(0.078) * * *$ \\
\hline Access to Irrigation (yes) & $0.117(0.326) * * *$ & $0.387(0.591) * * *$ & $-0.930(0.475) * *$ \\
\hline Access to credit (yes) & $0.057(0.306) *$ & $0.191(0.428)$ & $0.731(0.453) *$ \\
\hline Dependency Ratio & $-0.674(0.682)$ & $-0.291(0.972) * * *$ & $-0.697(0.962) * *$ \\
\hline Access to extension (yes) & $0.517(0.312) * *$ & $-0.412(0.437) * * *$ & $0.004(0.458) *$ \\
\hline Urban linkage (yes) & $0.220(0.325) * *$ & $-0.207(0.486) * * *$ & $0.159(0.516) * * *$ \\
\hline Mass media (yes) & $0.378(0.343) * * *$ & $0.441(0.509) * *$ & $0.602(0.510) * * *$ \\
\hline Total income & $0.001(0.001) *$ & $0.013(0.0002) * *$ & $0.002(0.001) *$ \\
\hline Access to road & $0.043(0.071) * * *$ & $-0.150(0.142) * *$ & $-0.217(0.151) * * *$ \\
\hline Climate (yes) & $0.137(0.341) * *$ & $0.760(0.506) * * *$ & $0.087(0.514) *$ \\
\hline cons & $-0.681(0.517) * * *$ & $0.114(0.750) * * *$ & $-3.135(0.857) * *$ \\
\hline
\end{tabular}

Significant codes: 0 ‘***’ $0.001^{\prime * * *} 0.01^{\text {' } * \text { ’ } 0.05}$

The results show that multinomial logit regression model for four levels of livelihood diversification strategies such as on farm only, on plus none farm, on plus off farm, and on plus off plus nonfarm with on farm only diversification strategy as a reference category were predicted. Hence, this analysis used agriculture on farm only diversification strategy only as the base category and evaluates the other choices as alternatives to this option. The first column of table, for instance, compared the choice of on farm and none farm, with on farm only, where the marginal effects and their signs reflect the expected change in probability of preferring to on farm only (the base) 
per unit change in an explanatory variable. Accordingly, the significant variables included; education attainment of households head, number of livestock, access to irrigation, access to credit, extension contact, urban linkage, access to mass media, distance to the nearest road, and climate change.

Livestock holding: the number of livestock is negatively influenced household's choice of farm only plus off-farm and non-farm diversification strategy (on, off and none farm) at $1 \%$ probability level. In contrary, it is found positively and significantly related with the choosing decision of diversification strategy of on farm plus off-farm diversification strategy (on and none farm) at $1 \%$ probability level. That means the household with lower livestock holding would be obliged to diversify his diversification into on farm only plus off-farm livelihood strategy, while the household with higher livestock holding would be obliged to household participate more in agriculture than livelihood diversification. The likelihood of diversifying in (on and off farm) strategies decrease by $39 \%$ and the likelihood of diversifying into on farm plus off farm and non-farm diversification strategy (on, off and none farm) decreases by $12.6 \%$ for households with more livestock number relative to the benchmark alternative on farm only.

Distance to the nearest road: this variable was found significant favorably at $10 \%$ to influence farmers' decision to diversify diversification strategy. Given all other variables in the model held constant, the likelihood of household head simultaneous choice of on farm and off-farm strategy relative to the base on farm only increase by $4.3 \%$ when the distance to the nearest road increase by one kilometer. This implies that the participation of the household head in on farm only plus off-farm strategy increase as they get far-off the nearest road. The possible reason is that farmers that are nearest to road is relatively access to sell their agricultural productivity than farm alone and could be pushed to engage in both on farm and off-farm strategy.

The dependency ratio: The dependency ratio found negatively and significantly correlated to the choice decision of on farm and off farm at $1 \%$ probability level. This means when the dependency ratio increases by a ratio, the ability of farmers to meet family needs decrease and chance of diversifying on farm plus off-farm strategy decreases. If the dependency ratio increases the probability of the household's to work on farm plus off-farm diversification strategy decreases by roughly $13 \%$. On the other hand, as expected, it was found negatively and significantly correlated with choice decision of the house hold to diversify all on, off and none farm. This implies that as family of inactive labor force increases by a ratio, the likely the household to decrease the choice decision on the diversification of on, off and none farm roughly by $17 \%$.

Educational attainment: Educational attainment affects diversification options. As expected Educational attainment of household head was found to be positively and significantly correlated at $10 \%$ probability level to diversification into on and none farm activities by the households. Thus, keeping the influence of other factors constant; the likelihood of literate household choice of on farm and off farm diversification strategy increases by $3 \%$. The opposite is true for the illiterate counterparts.

Climate change: The positive coefficient indicates that households that had seen the risk of climate changes are more probably engaged in on-farm only diversification strategy and less probably engaged in non-farm livelihood diversification strategy. If the other factors remain constant, the likelihood of adopting the on-farm plus non-farm strategy in favor of risk of climate changes increases by $14 \%$ and the opposite is true for households that had not seen the risk of climate changes with reference to the on-farm only strategy.

Land size: In line with expectation, land size was found to have positively significant relation to on farm plus none farm and on farm plus off farm plus none farm strategies at 5\% probability level respectively. One extra hectare land size of the household increases the likelihood of diversifying on farm plus none farm and on farm plus off farm plus none farm strategies increase by $77.5 \%$ and $9 \%$. The positive correlation between land size and diversification might be due to the relation between larger land size and wide farming land in order to meet basic needs to the agricultural farm land relative to the benchmark alternative agriculture only. Furthermore on large land size households are able to practice multiple activities whereas smaller ones tend to practice only agriculture with a livestock.

Mass media: Mass media is positively and significantly related to on-farm plus non-farm and a combination of on-farm, non-farm, and off-farm livelihood diversification strategies at $5 \%$ level of significance respectively. The positive coefficient indicates non/off-farm livelihood diversification is high in favor of the rural households having access to media. On the other hand, households having access to mass media are less likely to participate in on-farm only livelihood strategy. Holding the other factors constant, in favor of the respondents who listen to the radio and watching the television once in a week increases the probability of smallholder farming rural households' participation into on-farm plus non-farm, and a combination of three (on-farm, off-farm and non-farm) livelihood diversification strategies by $37.8 \%$ and $60 \%$ respectively. The possible reason could be that the access to mass media may improve rural households' information on non-farm prospects.

Urban linkage: As expected having link with the urban area peoples has a positive and significant influence on on-farm plus non-farm, and a combination of the three (on-farm plus non-farm plus off farm) diversification strategies at less than $5 \%$ level of significance in the reference to on-farm only strategy. The positive coefficient indicates that if the other factors are remain constant, the probability of the households who have connection with 
urban inhabitants probability of diversification into on-farm plus non-farm, and a combination of the three (onfarm plus non-farm plus off-farm) activities the marginal effects increased by $22 \%$ and $16 \%$ respectively. This could be that having relatives in the urban area improves the farm households' information on non/off-farm diversification opportunities. This suggests that improving rural-urban linkages could facilitate non/off-farm diversification strategies.

Extension contact: For on plus none farm diversification strategy, the coefficients of extension contact tell us that higher contact frequency and higher increase the likelihood that the household will have practice on plus none farm diversification strategy that incidents as supported to none. That means, household that have a good contact with extension program workers are less likely to be any of the diversification strategy practices on farm plus none farm $(0.517)$, on farm plus off farm $(-0.412)$, or on farm plus none farm plus off farm $(0.004)$, when controlling for other predictors.

Access to irrigation: The coefficients of access to irrigation results suggest that the households that had an access to irrigation had less likely to choose all on farm plus none farm plus off farm collectively even stronger than it was without controlling. The result shows that on plus none farm activities are less likely to be implemented by the households that had an access to irrigation.

Access to credit: As estimated, access to credit has a positive correlation and somewhat significant with diversification strategy at 5\% probability level. The multinomial logit estimate for an increase in access to credit with on plus off plus none diversification strategy to the base variable on farm alone, given the other variables in the model are held constant. If a subject were to increase access to credit, the multinomial odds ratio for choice of on plus off plus none diversification strategy relative to the base variable on farm alone would be expected to increase by $73 \%$.

Total income: Total income variable found to have positive and significant influence on households' choice of on-farm plus non-farm and combination of on-farm, non-farm plus off-farm livelihood and negative for onfarm plus off-farm diversification strategies at less than $5 \%$ probability level. The positive coefficient implies that households with large total household income are more likely to diversify the diversification strategies into nonfarm and/or off-farm activities. The possible reason can be farm households with large total income can invest in alternative diversification strategies, especially in non-farm activities. From the model result, other things being constant, the marginal effect reveals that the probability of a household diversifying into non-farm, off-farm, and combined non-farm and off-farm activities increased by $0.1 \%, 1.3 \%$ and $0.2 \%$, respectively, for those farm households with more level of income.

\section{Conclusion and Recommendations}

\subsection{Conclusion}

This thesis attempts to investigate the determinants of rural households, choice of diversification strategies. The data for this study was obtained based on survey questionnaires from 292 household head selected using multi stages random and purposive sampling technique in the rural areas of Limmu district at house hold level. Multinomial logit regression was applied to identify the likelihood choice of diversification strategies selected by rural household heads. The result of the descriptive statistics showed the majority of the sample households only $12.33 \%$ allocate all their labor to agricultural activities, while about $46 \%$ engaged in on farm and nonfarm combination diversification strategy, only $30 \%$ of the sample rural household's work on farm, off farm and nonfarm combination income generation livelihood strategy.

The result of the multinomial logistic regression model revealed that out of 19 variables included in the model only 12 explanatory variables were found to be significant at different probability level. Accordingly, the dependency ratio, livestock holding, distance to the nearest road, income, access to irrigation, education attainment, access to credit, climate change and land size were included in the model. But the rest were insignificant variables. The livestock holding, dependency ratio and access to credit were partially positively and significantly related to diversification strategy respectively.

\subsection{Recommendations}

The study founds diversification strategy households to increases the probability of their maintaining diversification security, basically appreciation of the way that combinations activities secure livelihoods. Thus, from the study, the following recommendation can be made:

1. The result of the study showed that livestock holding have a significant correlation with the livelihood diversification strategies. Therefore, targeting farmers with livestock holding by giving due attention the quality aspects and emphasizing on disease problems of the area will increases the probability of farmers' choice decision on diversification strategies. Therefore the rural diversification strategy should not only emphasis in increasing agricultural production but attention should be given in promoting combination activities in diversifying livestock value added products for income generating activities.

2. Access to the nearest road is another important factor affecting livelihood strategies. Distance to the road was 
negatively and significantly associated to the choice of diversification strategy. A household who have access to nearest road have higher involvement in diversification strategy. Therefore, infrastructure in rural areas should construct for labor mobility to enhance agricultural diversification strategies. Infrastructure (particularly roads, telecommunications and electricity) affects both opportunities and access.

3. The study suggests that efforts should focus on government policies and strategic plans that support the promotion of incentive to diversify diversification strategy in combination of agriculture, non-farm and offfarm options, substitution between assets and activities to diversify household livelihood through encouraging entrepreneur, enhancing employment opportunities, support for self-employment, especially in rural areas where farming currently predominates. Design policy and intervention that facilitates livelihood diversification in generating income sources for the rural poor. Provide information and advice on diversification opportunities.

\section{References}

Admit Wondifraw, James Wakiaga, Haile Kibret (2016) Ethiopia_African Economic Outlook (2016). WEB www.africaneconomicoutlook.org

Ahmed, M.T., Bhandari, H., Gordoncillo, P.U., Quicoy, C.B., \& Carnaje, G.P. (2015). Diversification of rural livelihoods in Bangladesh. Journal of Agricultural Economics and Rural Development, 2(2), 032-037.

Alobo Loison S. (2015). Rural livelihood diversification in sub-Saharan Africa: a literature study. J Dev Stud. 2015;51(9):1125-38

Asfaw A (2018). Study on determinants of sustainable rural livelihood diversification of smallholder farmers in Ethiopia. International Journal Advanced Research 6(2):251-259

Barrett CB, Reardon T, Webb P. (2001). Non-farm income diversification and household livelihood strategies in rural Africa: concepts, dynamics, and policy implications. Food Policy. 2001;26(4):315-31.

Beyene, AD. (2008). Determinants of off-farm participation decision of farm households in Ethiopia. Agrekon, Vol 47, No 1. 140-161.

Centeral Statistical Authority (CSA). (2016). Central Statistical Authority population estimates in Ethiopia, Addis Ababa.

Chambers JK. (1995) Sociolinguistic theory. New York: Blackwell; 1995.

Cochran, W. G. (1963). Sampling Techniques, 2nd Ed., New York: John Wiley and Sons, Inc.

Davis, B., et al. (2010). A cross-country comparison of rural income generating activities. World Dev, 38(1), 4863.

Dessalegn Rahmato. (2009). The Peasant and the State: Studies in Agrarian Change, 1950s-2000s, Addis Ababa: Addis Ababa University Press.

Ellis F. (2000). The determinants of rural livelihood diversifcation in developing countries. J Agric Econ. 2000;51(2):289-302

FAO. (2015). The State of Food Insecurity in the World 2015. Meeting the 2015 International Hunger Targets: Taking Stock of Uneven Progress; FAO: Rome, Italy, 2015; pp. 1-62

Gebru et al. (2018). Determinants of livelihood diversifcation strategies in Eastern Tigray Region of Ethiopia. Agriculture \& Food Security (2018) 7:62

Green, H.W., (2003). Econometric Analysis: Fourth Edition. New York University Macmillan Publishing company.

Hegde, N.G. (2002). Challenges of rural development and opportunities for providing sustainable livelihood: BAIF's Approach. International Forum on Frontier Technology for the 21st Century and Potential Collaboration with Kasetsart University, Bangkok, Thailand. May 30-31, 2002.

Kassie, G.W. (2017). The Nexus between livelihood diversification and farmland management strategies in rural Ethiopia. Cogent Econ. Financ. 2017, 5, 1-16. [CrossRef]

Lemi A (2009). Determinants Of Income Diversification In Rural Ethiopia: Evidence From Panel Data. Ethiopian Journal of Economics 18:1.

Mahendra Dev (2011) Climate Change, Rural Livelihoods and Agriculture (focus on Food Security) in AsiaPacific Region: Indira Gandhi Institute of Development Research (IGIDR), WP-2011-014; August 2011.

Rosegrant, M.W. et al. (2002). The Role of Rainfed Agriculture in the Future of Global Food Production; IFPRI: Washington, DC, USA, 2002.

Sarah A (2015). Rural Livelihood Diversification in Sub-Saharan Africa: A Literature Study, The Journal of Development Studies DOI: 10.1080/00220388.2015.1046445

Sisay B (2013). Study on Rural livelihood diversification among the smallholder farmers in some Africa countries. International Journal of Agricultural Economics Extension and Rural Development 1(1):010- 016.

Wagayehu Bekele, (2004). Analysis of Farmers' Preferences for Development Intervention Programs: A Case Study of Subsistence Farmers from Eastern Ethiopian Highlands, African Development and Poverty Reduction, the macro-micro linkage policy paper, South Africa. 
Wassie Berehanu, Colman, D. and Bichaka, F. (2008). Diversification and Livelihood Sustainability in a Semi-arid Environment: A Case Study from Southern Ethiopia.

\section{Appendix}

Table 3.1: Frequency Distribution of Selected Categorical Variables

\begin{tabular}{|c|c|c|c|}
\hline Variable & Variable Labels & Freqency & Percent \\
\hline Kebele & $\begin{array}{l}\text { Degem Sillasie } \\
\text { Gaba Kamisa } \\
\text { Arkumbe }\end{array}$ & $\begin{array}{l}112 \\
31 \\
149\end{array}$ & $\begin{array}{l}38.36 \\
10.62 \\
51.03\end{array}$ \\
\hline Sex of Household head & $\begin{array}{l}\text { female } \\
\text { male }\end{array}$ & $\begin{array}{l}69 \\
223 \\
\end{array}$ & $\begin{array}{l}23.63 \\
76.37 \\
\end{array}$ \\
\hline Diversification strategy & $\begin{array}{l}\text { on farm } \\
\text { On }+ \text { none farm } \\
\text { On }+ \text { off farm } \\
\text { On }+ \text { off }+ \text { none farm }\end{array}$ & $\begin{array}{l}134 \\
87 \\
35 \\
36\end{array}$ & $\begin{array}{l}45.89 \\
29.79 \\
11.99 \\
12.33\end{array}$ \\
\hline age of household head & $\begin{array}{l}<16 \text { years } \\
17-50 \text { years } \\
>50 \text { years }\end{array}$ & $\begin{array}{l}2 \\
250 \\
40 \\
\end{array}$ & $\begin{array}{l}0.68 \\
85.62 \\
13.70 \\
\end{array}$ \\
\hline education of house hold head & $\begin{array}{l}\text { Illiterate } \\
\text { Literate }\end{array}$ & $\begin{array}{l}136 \\
156\end{array}$ & $\begin{array}{l}46.58 \\
53.42\end{array}$ \\
\hline Access to irrigation & $\begin{array}{l}\text { no } \\
\text { yes }\end{array}$ & $\begin{array}{l}151 \\
141\end{array}$ & $\begin{array}{l}51.71 \\
48.29\end{array}$ \\
\hline Access to credit & $\begin{array}{l}\text { no } \\
\text { yes }\end{array}$ & $\begin{array}{l}149 \\
142\end{array}$ & $\begin{array}{l}51.20 \\
48.80\end{array}$ \\
\hline Cooperative membership & $\begin{array}{l}\text { no } \\
\text { yes }\end{array}$ & $\begin{array}{l}61 \\
230\end{array}$ & $\begin{array}{l}20.96 \\
79.04\end{array}$ \\
\hline Extension contact & $\begin{array}{l}\text { no } \\
\text { yes }\end{array}$ & $\begin{array}{l}127 \\
165\end{array}$ & $\begin{array}{l}43.49 \\
56.51\end{array}$ \\
\hline Urban linkage & $\begin{array}{l}\text { no } \\
\text { yes }\end{array}$ & $\begin{array}{l}142 \\
150\end{array}$ & $\begin{array}{l}48.63 \\
51.37\end{array}$ \\
\hline Access to mass media & $\begin{array}{l}\text { no } \\
\text { yes }\end{array}$ & $\begin{array}{l}141 \\
151\end{array}$ & $\begin{array}{l}48.29 \\
51.71\end{array}$ \\
\hline Crop risk & $\begin{array}{l}\text { no } \\
\text { yes }\end{array}$ & $\begin{array}{l}101 \\
191\end{array}$ & $\begin{array}{l}34.59 \\
65.41\end{array}$ \\
\hline \multirow[t]{2}{*}{ Climate change } & $\begin{array}{l}\text { no } \\
\text { yes }\end{array}$ & $\begin{array}{l}92 \\
200\end{array}$ & $\begin{array}{l}31.51 \\
68.49\end{array}$ \\
\hline & Total & 292 & 100.00 \\
\hline
\end{tabular}

